\title{
Response Detection of Castrate-Resistant Prostate Cancer to Clinically Utilised and Novel Treatments by Monitoring Phospholipid Metabolism
}

\author{
Tim A. D. Smith, Su M. Phyu, Kholoud S. Alzyoud, and Chih-Chung Tseng \\ School of Medicine, Medical Sciences and Nutrition, University of Aberdeen, Foresterhill, Aberdeen AB25 2ZD, UK \\ Correspondence should be addressed to Tim A. D. Smith; t.smith@abdn.ac.uk
}

Received 22 March 2017; Accepted 30 May 2017; Published 22 June 2017

Academic Editor: Christian Schwentner

Copyright (C) 2017 Tim A. D. Smith et al. This is an open access article distributed under the Creative Commons Attribution License, which permits unrestricted use, distribution, and reproduction in any medium, provided the original work is properly cited.

\begin{abstract}
Androgen receptor (AR) activation is the primary driving factor in prostate cancer which is initially responsive to castration but then becomes resistant (castration-resistant prostate cancer (CRPC)). CRPC cells still retain the functioning AR which can be targeted by other therapies. A recent promising development is the use of inhibitors (Epi-1) of protein-protein interaction to inhibit ARactivated signalling. Translating novel therapies into the clinic requires sensitive early response indicators. Here potential response markers are explored. Growth inhibition of prostate cancer cells with flutamide, paclitaxel, and Epi-1 was measured using the MTT assay. To simulate choline-PET scans, pulse-chase experiments were carried out with $\left[{ }^{3} \mathrm{H}\right.$-methyl]choline and proportion of phosphorylated activity was determined after treatment with growth inhibitory concentrations of each drug. Extracts from treated cells were also subject to ${ }^{31} \mathrm{P}-\mathrm{NMR}$ spectroscopy. Cells treated with flutamide demonstrated decreased $\left[{ }^{3} \mathrm{H}\right.$-methyl]choline phosphorylation, whilst the proportion of phosphorylated $\left[{ }^{3} \mathrm{H}\right.$-methyl]choline that was present in the lipid fraction was increased in Epi-1-treated cells. Phospholipid breakdown products, glycerophosphorylcholine and glycerophosphoethanolamine levels, were shown by 31P-NMR spectroscopy to be decreased to undetectable levels in cells treated with Epi-1. LNCaP cells responding to treatment with novel protein-protein interaction inhibitors suggest that ${ }^{31} \mathrm{P}-\mathrm{NMR}$ spectroscopy may be useful in detecting response to this promising therapy.
\end{abstract}

\section{Introduction}

Prostate cancer is the second most commonly diagnosed cancer and the 6th leading cause of death in men worldwide [1]. Most prostate cancers are initially sensitive to antiandrogen treatment and advanced stage cases of prostate cancer are treated by antiandrogen therapy, for example, by castration, but such cancers later develop resistance (castrate-resistant prostate cancer (CRPC)) although they are still dependent on the AR (androgen receptor) for growth. The taxane docetaxel has demonstrated some improvement in survival of patients with CRPC and is recommended for patients with CRPC [2].

The development of AR-targeting compounds that can inhibit the growth of CRPC cells is a major step forward in the treatment of this disease. Protein-protein interaction inhibitors are a rapidly emerging class of drugs in anticancer drug development which demonstrate effective therapeutic efficacy towards tumours refractory to other treatments. Work has demonstrated that targeting the androgen receptor with the protein-protein inhibitor molecule family $3-(4-\{2-$ [4-(3-chloro-2-hydroxypropoxy)phenyl]-2-propanyl\}phenoxy)-1,2-propanediol (Epi-1) can halt the growth of CRPC cells by inhibiting androgen receptor mediated intracellular signalling [3].

Anticancer treatments are often associated with detrimental side-effects $[4,5]$. Early detection of response status can be used to tailor a patient's treatment facilitating cessation of noneffective treatments. Early response detection can also assist in the clinical translation of novel anticancer agents [6]. Molecular imaging techniques such as PET (positron emission tomography) and MRS (magnetic resonance spectroscopy) are sensitive, noninvasive methods for early response detection [7] and cell based studies have shown that changes in metabolite utilisation are early markers 
of response [8]. FDG ( $\left[{ }^{18} \mathrm{~F}\right]$ fluoro-2-deoxy-D-glucose) is an unsuitable tracer for imaging the prostate as it is excreted via the kidney so patient FDG-PET scans inevitably show high activity in the pelvic region which will obscure uptake by the prostate gland. However prostate cancer has a high affinity for the phospholipid metabolite, choline, and consequently can be imaged using $\left[{ }^{11} \mathrm{C}\right]$ choline-PET [9]. Further, AR activation in prostate cancer induces signalling via the calcium/calmodulin dependent kinase kinase 2- (CAMKK2-) AMPK signalling pathway which amongst other effects controls phospholipid metabolism so inhibition of signalling via the AR would be expected to induce early changes in phospholipid metabolism which can be probed noninvasively using 31P-NMR spectroscopy. ${ }^{31} \mathrm{P}-\mathrm{NMR}$ spectroscopy detects the concentration of several phospholipid metabolites including glycerophosphorylcholine (GPC) and phosphocholine (PC) which in some cells has been shown to be associated with proliferation rate [10].

Here prostate cancer cells untreated and treated with flutamide, paclitaxel, or Epi-1 were subject to pulse-chase measurements with $\left[{ }^{3} \mathrm{H}\right.$-methyl $]$ choline (which is chemically identical to $\left[{ }^{11} \mathrm{C}\right]$ choline) and ${ }^{31} \mathrm{P}-\mathrm{NMR}$ spectroscopy to assess the modulatory effect of these drugs on phospholipid metabolism.

\section{Methods}

2.1. Chemicals and Cells. Androgen receptor positive LNCaP prostate cancer cell lines were obtained from the European Collection of Cell Cultures (ETACC). Cells were grown in Dulbecco's Modified Eagle's Medium supplemented with glutaMAX ${ }^{\mathrm{TM}}$ (Gibco UK), 10\% charcoal stripped serum, and 10,000 units penicillin/10,000 $\mu \mathrm{g}$ and streptomycin per $100 \mathrm{ml}$ of medium. Cells were supplemented in all experiments with the androgen R1881 $(1 \mu \mathrm{g} / \mathrm{ml})$. [ ${ }^{3} \mathrm{H}$-methyl] choline $(2.96 \mathrm{TBq} / \mathrm{mmol})$ was obtained from American Radiochemical Corporation Inc., USA. All chemicals were obtained from Sigma-Aldrich (Poole, UK) unless otherwise stated.

\subsection{Determination of Drug Induced Cell Growth Inhibition} Using the MTT Assay. The cell growth inhibiting effect of anticancer drugs was initially tested using the MTT assay. LNCaP cells in medium $(100 \mu \mathrm{l})$ were seeded into 96-well plates $(75,000$ cells $/ \mathrm{ml})$ and incubated for $24 \mathrm{~h}$ at $37^{\circ} \mathrm{C}$ in a $\mathrm{CO}_{2}$ incubator and then treated with a range of drug concentrations for $72 \mathrm{~h}$ at $37^{\circ} \mathrm{C}$. Cell number in each well is then determined using the 3-(4,5-dimethylthiazol-2-yl)-2,5diphenyl tetrazolium bromide (MTT) dye which is converted to a purple colour by mitochondria in viable cells. The intensity of the purple colour, which is proportional to the cell number, was then determined using a scanning multiwell plate reader (MR5000 Dynatech Laboratories Inc., USA) with the absorbance at $540 \mathrm{~nm}$.

2.3. Pulse-Chase $\left[{ }^{3} H\right.$-methyl]choline. The pulse-chase technique simulates exposure of cancer cells in patients to blood levels of $\left[{ }^{11} \mathrm{C}\right.$ ]choline. LNCaP cells $\left(10^{6}\right.$ in $5 \mathrm{ml}$ of medium) were seeded in $25 \mathrm{~cm}^{2}$ flasks and allowed to establish for $24 \mathrm{~h}$. The cells were then either left untreated or treated with drugs for $48 \mathrm{~h}$ after which medium was removed and replaced with $1 \mathrm{ml}$ of medium containing $37 \mathrm{KBq}$ of $\left[{ }^{3} \mathrm{H}\right.$-methyl] choline. After 15 mins, the cells were rapidly washed $3 \mathrm{x}$ with ice-cold phosphate buffered saline (Sigma, Poole, UK), then incubated with nonradioactive medium for $1 \mathrm{~h}$. Medium was collected and radioactivity counted and the cells were trypsinized by addition of $0.35 \mathrm{ml}$ of trypsin ( $0.05 \%$ trypsin/EDTA). After the cells were detached, $0.35 \mathrm{ml}$ of medium was added and the cells transferred to $1.5 \mathrm{ml}$ microfuge tubes which were centrifuged at $200 \mathrm{~g}$ for $5 \mathrm{~min}$. The cells were washed by addition of $1 \mathrm{ml}$ of PBS and further centrifugation. The supernatant and medium were combined and subject to phosphate measurement (see below). The cells were subject to fractionation into lipid and aqueous fractions (see below).

2.4. Lipid and Aqueous Fractionation. Cells were suspended in $0.375 \mathrm{ml}$ of chloroform: methanol $(1: 2)$ and left on ice for $1 \mathrm{~h}$ with occasional mixing. Separation of the phases was then achieved by addition of $125 \mu \mathrm{l}$ of $10 \mathrm{mM}$ TRIS buffer and $125 \mu \mathrm{l}$ of chloroform followed by centrifugation at $10,000 \mathrm{~g}$ for $10 \mathrm{~min}$ at $4^{\circ} \mathrm{C}$. The upper phase was then removed and subject to phosphate measurement. The lipid phase was removed by carefully accessing with a pipette tip through the cell residue at interface. Radioactivity in the lipid phase was measured by scintillation counting. The cell residue (mainly protein) was dried in the microfuge tubes and then dissolved in $100 \mu \mathrm{l}$ of $\mathrm{NaOH}(1 \mathrm{M})$. A protein assay (Bicinchoninic Acid Protein Assay Kit, Sigma, UK) was carried out on the dissolved pellet after neutralisation with $\mathrm{HCl}$ and used to normalise the data for differences in cell number between treated and untreated cells.

2.5. Determination of Proportion of Phosphorylated $\left[{ }^{3} \mathrm{H}\right.$-meth$y l] c h o l i n e$. Aqueous extracts and cell washes were subject to measurement of phosphorylated $\left[{ }^{3} \mathrm{H}\right.$-methyl $]$ choline [11, 12]. Briefly, the total radioactivity in each of the sample was measured using part of each sample and correcting for volume. Phosphates (which included any phosphorylated $\left[{ }^{3} \mathrm{H}\right.$-methyl $]$ choline) were precipitated by addition of equal volumes of $\mathrm{Ba}(\mathrm{OH})_{2}(0.3 \mathrm{M})$ and $\mathrm{ZnSO}_{4}(5 \% \mathrm{w} / \mathrm{v})$ and centrifugation at $10,000 \mathrm{~g}$ for $10 \mathrm{~min}$ to remove the precipitated phosphates. The nonphosphorylated $\left[{ }^{3} \mathrm{H}\right.$-methyl]choline was then determined in the supernatant. The proportion of phosphorylated $\left[{ }^{3} \mathrm{H}\right.$-methyl $]$ choline was determined by subtraction after correcting for dilution [13] from total. The total and phosphorylated activity (including the lipid fraction) were summated and the proportion of phosphorylated activity was determined.

2.6. Sample Preparation for ${ }^{31} P-N M R$ Spectroscopy. Cells were seeded in $80 \mathrm{~cm}^{2}$ tissue culture flasks and allowed to establish for $24 \mathrm{~h}$. The cells were then either left untreated or treated with drugs for $48 \mathrm{~h}$ after which medium was removed and the cells washed $3 \mathrm{x}$ with $10 \mathrm{ml}$ PBS. The cells were then detached with trypsin $(3 \mathrm{ml})$ and, after addition of medium $(3 \mathrm{ml})$, the cells were centrifuged at $200 \mathrm{~g}$ for $5 \mathrm{~min}$. The pellet was suspended in isotonic saline and transferred to a $1.5 \mathrm{ml}$ microfuge tube and washed $3 \mathrm{x}$ with ice-cold isotonic saline, 


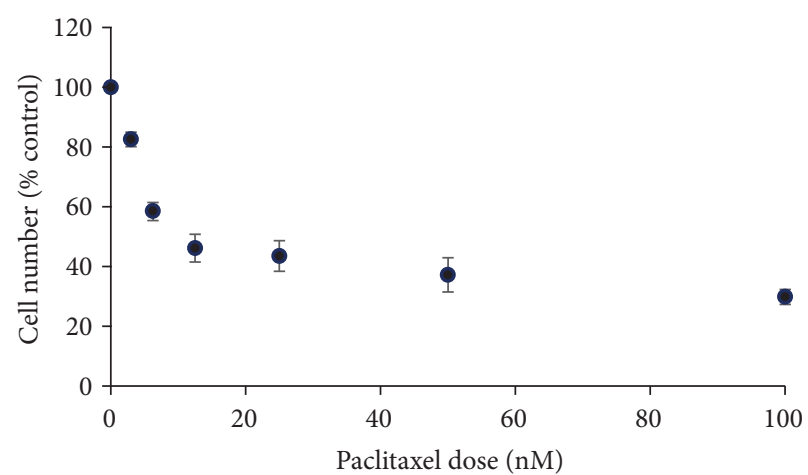

(a)

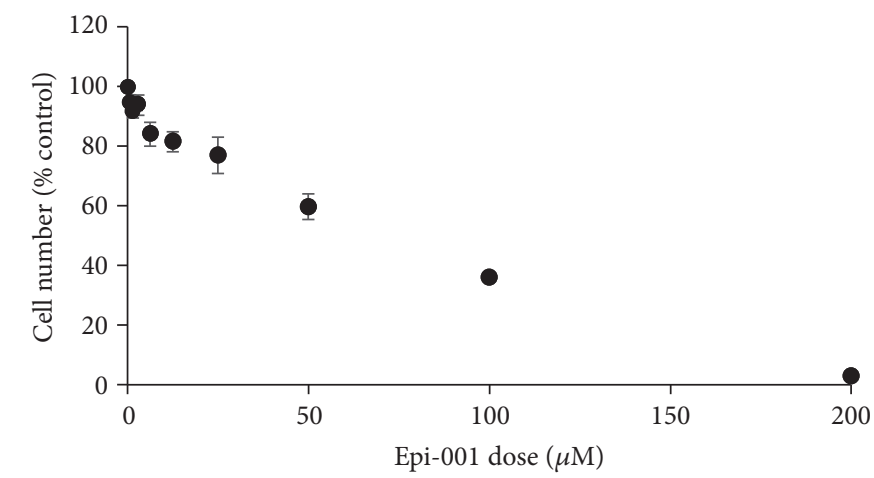

(b)

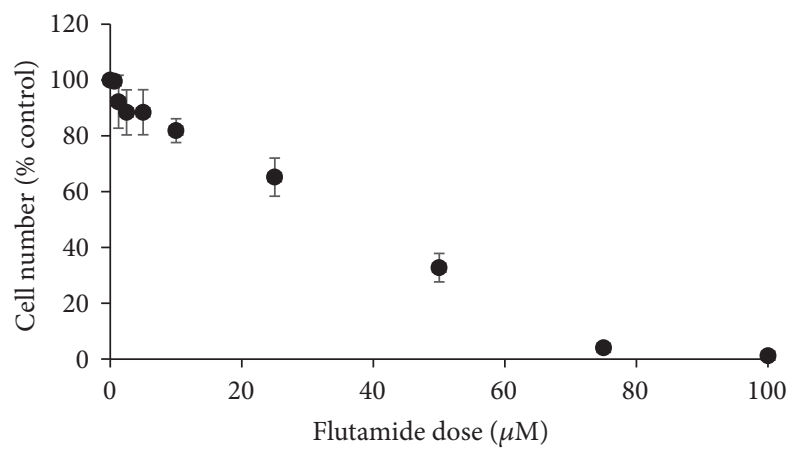

(c)

FIGURE 1: Growth of LNCaP cells treated with paclitaxel (taxol) (a), flutamide (b), or Epi-1 (c) relative to untreated cells.

each time centrifuging at $200 \mathrm{~g}$ for $5 \mathrm{~min}$ at $4^{\circ} \mathrm{C}$. The pellet was then subject to lipid and aqueous fractionation as described above except $10 \mathrm{mM}$ EDTA and a standard consisting of 1aminopropylphosphoric acid $(0.3 \mu$ moles $)$ was added to the initial $0.375 \mathrm{ml}$ of chloroform and methanol. After extraction and phase separation, the aqueous phase was collected and made up to a volume of $0.6 \mathrm{ml}$ by addition of $\mathrm{D}_{2} \mathrm{O}$. The lipid fraction was spiked with the standard tetramethylsilane (TSP) $(0.6 \mu$ moles $)$ and subject to ${ }^{1} \mathrm{H}$ NMR analysis.

2.7. ${ }^{31} P-N M R$ and ${ }^{1} H-N M R$ Spectroscopy. NMR analysis was carried out on a Bruker AVANCE III $400 \mathrm{MHz}$ NMR spectrometer operating at $161.98 \mathrm{MHz}$ for ${ }^{31} \mathrm{P}$ with broadband ${ }^{1} \mathrm{H}$ decoupling and run overnight (to acquire 20,000 scans) at $25^{\circ} \mathrm{C}$. The parameters for each acquisition were as follows: acquisition time $1.258 \mathrm{~s}$; relaxation delay $1 \mathrm{~s}$ (peak sizes were similar when $1 \mathrm{~s}$ or $2 \mathrm{~s}$ were used suggesting complete relaxation in 1s); pulse angle $45^{\circ}$. At least three independent experiments were carried out and analysed per treatment. Metabolite concentrations were determined by comparison with the standard $(0.3 \mu$ moles $)$ resonating at $11.8 \mathrm{ppm}$.

$1 \mathrm{H}-\mathrm{NMR}$ spectra, acquired on the lipid extracts, were run for 200 scans with a relaxation delay of $5 \mathrm{~s}$ and a $90^{\circ}$ pulse angle.

2.8. Statistical Analysis. Significant differences between means were tested using Student's $t$-test. All experiments were carried out at least 3 times.

\section{Results and Discussion}

Figure 1 shows the effect of paclitaxel, Epi-1, and flutamide on the growth of LNCap cells. Growth inhibition of LNCaP cells with paclitaxel achieves a plateau at about $10 \mathrm{nM}$. A similar effect has been noted previously [14] with this drug. Both Epi-1 and flutamide inhibited growth in a concentrationdependent manner. For subsequent experiments, doses were chosen that decreased growth by about $30 \% 5 \mathrm{nM}$ paclitaxel, $40 \mu \mathrm{M}$ Epi-1, and $20 \mu \mathrm{M}$ flutamide.

Total $\left[{ }^{3} \mathrm{H}\right.$-methyl]choline uptake, percent phosphorylated, and percent phosphorylated in lipid are shown in Figure 2. Total uptake is unaffected by each drug treatment, but the percentage of phosphorylated $\left[{ }^{3} \mathrm{H}\right.$-methyl $]$ choline is significantly $(p<0.01)$ decreased in cells treated with flutamide. To better understand the intracellular fate of the phosphorylated $\left[{ }^{3} \mathrm{H}\right.$-methyl $]$ choline, activity in the lipid fraction was determined and found to be significantly $(p<0.01)$ increased in cells treated with Epi-1. However, steady-state PtdCho content, determined by analysis of the choline peak (Figure 3) resonating at $3.4 \mathrm{ppm}$ in the ${ }^{1} \mathrm{H}$ spectra acquired from the lipid phase of cell extracts, was not significantly increased in cells treated with Epi $(1.12 \pm 0.23 \mu \mathrm{mol} / \mathrm{mg}$ protein $)$ compared with control cells $(0.99 \pm 0.03 \mu \mathrm{mol} / \mathrm{mg}$ protein $)$. PtdCho transfer protein (PC-TP) is involved in preserving steadystate membrane phospholipid content in cells in response to cellular lipid efflux. PC-TP is associated with the steroidal ${ }^{31} \mathrm{P}$ NMR spectroscopy that can detect phospholipid metabolites in cells and cell extracts $[15,16]$ and is clinically translatable 


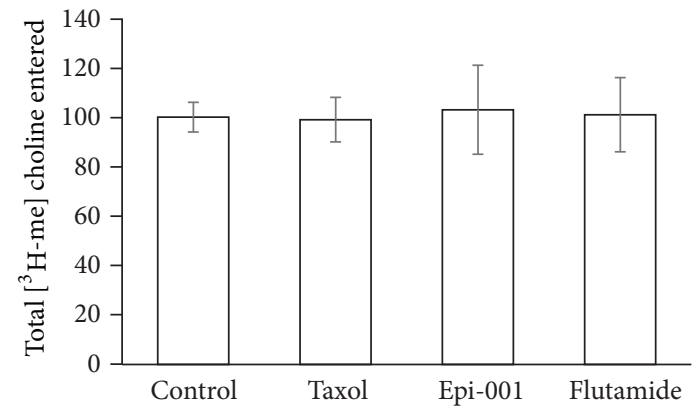

(a)

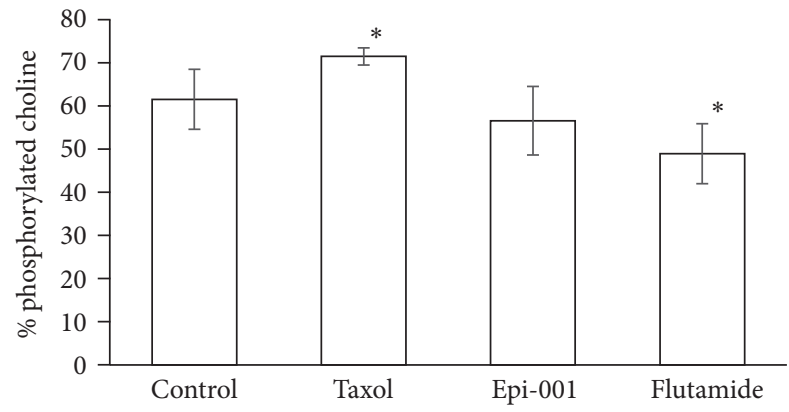

(b)

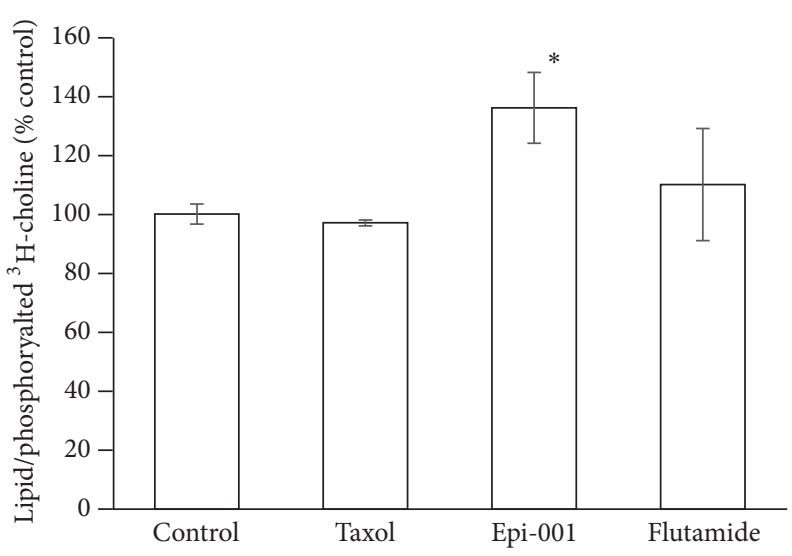

(c)

Figure 2: Total $\left[{ }^{3} \mathrm{H}\right.$-methyl $]$ choline uptake (a), phosphorylated $\left[{ }^{3} \mathrm{H}\right.$-methyl $]$ choline (as a \% of total uptake) (b), and incorporation of $\left[{ }^{3} \mathrm{H}\right.$-methyl]choline into lipid relative to phosphorylated $\left[{ }^{3} \mathrm{H}\right.$-methyl]choline $(\mathrm{c})(*$ indicates statistically significant change compared with control).

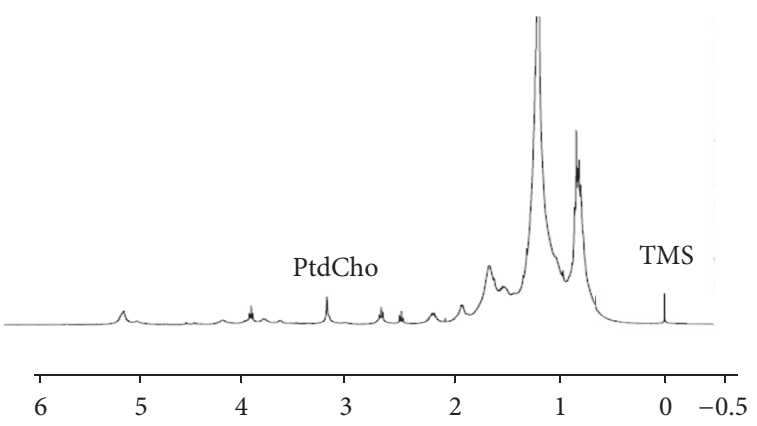

FIGURE 3: ${ }^{1} \mathrm{H}-\mathrm{NMR}$ spectrum acquired from the lipid extract prepared from control LNCaP cells showing location of PtdCho resonance and the standard TMS ( $x$-axis: $\mathrm{ppm})$.

[17]. Figure 4(a) shows a ${ }^{31} \mathrm{P}-\mathrm{NMR}$ spectrum acquired on an aqueous extract from untreated LNCaP cells. The standard resonates at $11.8 \mathrm{ppm}$, the phospholipid metabolites $\mathrm{PE}$ (phosphoethanolamine) and PC (phosphocholine) resonate at 3.75 and $3 \mathrm{ppm}$, respectively, inorganic phosphorus resonates at $1.2 \mathrm{ppm}$, the phospholipid catabolites GPE and GPC resonate at 0.5 and $-0.5 \mathrm{ppm}$, respectively, $\mathrm{PCr}$ resonates at -3.1 , and $\gamma, \alpha$, and $\beta$ NTP (nucleotide triphosphates) resonate at $-7.5 \mathrm{ppm},-11$, and $-22 \mathrm{ppm}$, respectively. Phosphorus in NAD (nucleotide adenine dinucleotide) resonates at -11.5 and DPDE (diphosphodiesters) at $-13 \mathrm{ppm}$.
Figure 5 shows mean $( \pm \mathrm{SD})$ of each metabolite. In common with other studies [15], phospholipid metabolism was examined after $48 \mathrm{~h}$ treatments [18]. There is no significant change in the content of any of the metabolites in cells treated with either flutamide or paclitaxel compared with untreated cells. However treatment of prostate cancer cells with Epi-1 was associated with decreased levels of GPC and GPE to undetectable levels. A study [19] has shown that the level of GPC in aggressive basal-type breast tumours is greater than in the less aggressive luminal tumours. A study [20] using a inhibition of HIF1 inhibitor PX-478 which, in common with the AR-stimulated prostate cancer growth [21, 22], is associated with AMPK signalling [23] demonstrated decreased GPC in human colorectal cancer cells. A recent study [24] has demonstrated excellent resolution of PC, PE, GPC, and GPE 31P-NMR spectra in vivo from patients with prostate cancer using a $7 \mathrm{~T}$ system suggesting that this method could be utilised in detecting response to Epi-1.

GPC and GPE are phospholipid degradation products and have been considered measures of dynamic membrane turnover [19]. The complex role of GPC in cancer is very difficult to understand and elucidating the mechanism of therapy-induced changes in GPC is likely to be challenging [25]. GPC/E levels are the net result of several different enzyme activities including Phospholipase A2, group IV A/B, Lysophospholipase 1/2, Phospholipase B1, Phospholipase A2G3, Phospholipase A2G10, and Phospholipase A2G12A 


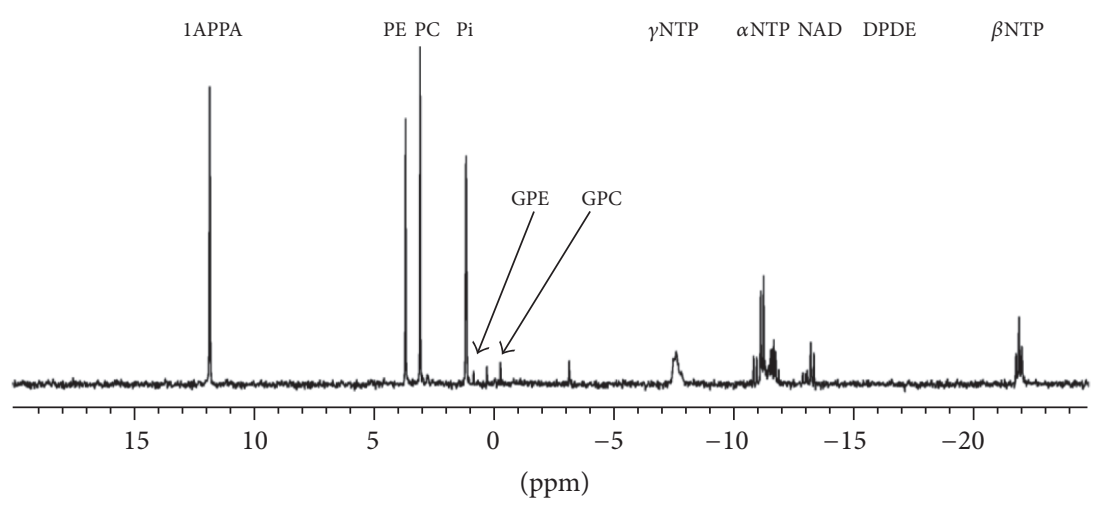

(a)

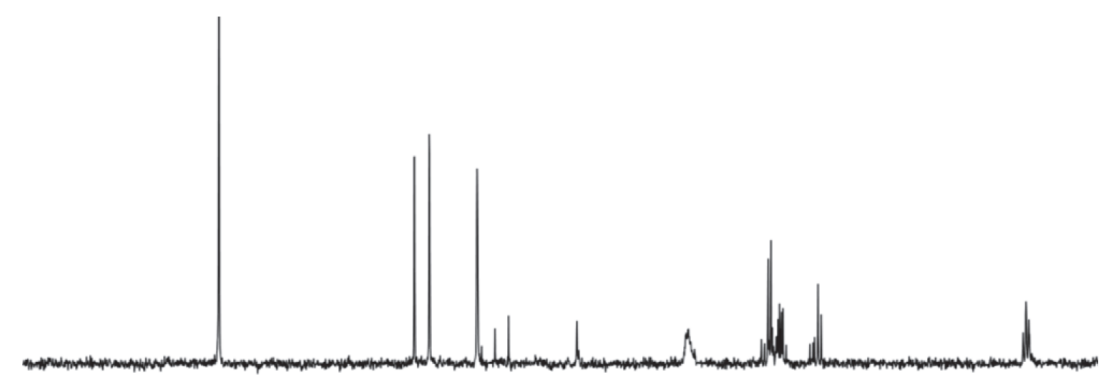

(b)

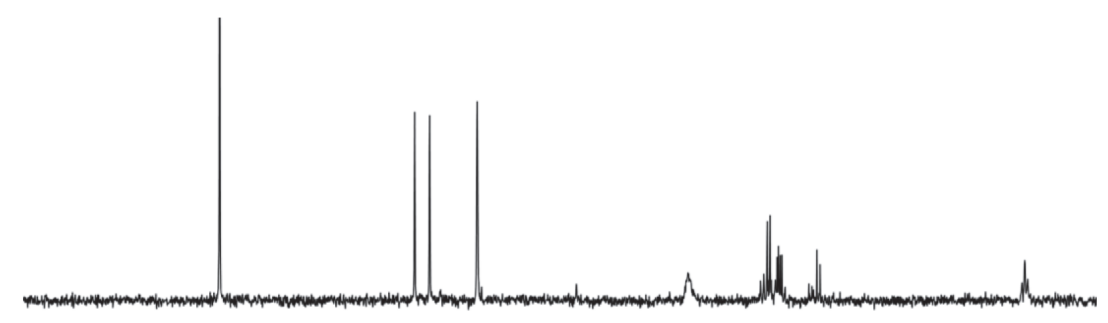

(c)

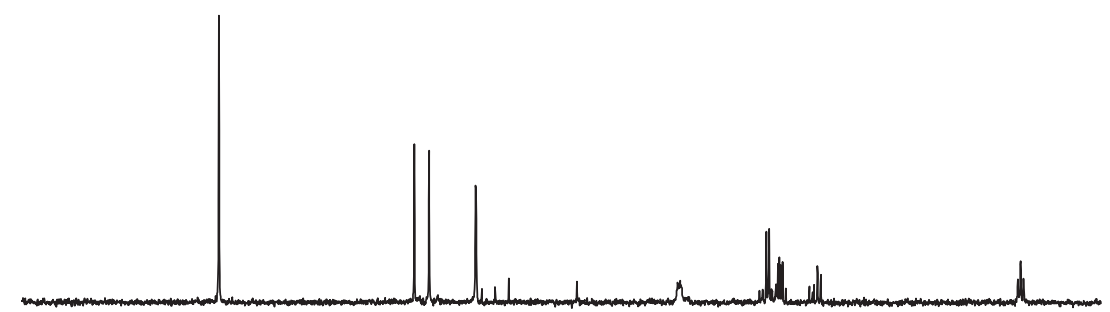

(d)

FIGURE 4: ${ }^{31} \mathrm{P}-\mathrm{NMR}$ spectra acquired from chemical extracts (aqueous) prepared from untreated LNCaP cells (a) or LNCaP cells treated for $48 \mathrm{~h}$ with paclitaxel $(5 \mathrm{nM})(\mathrm{b})$, Epi-1 $(40 \mu \mathrm{M})(\mathrm{c})$, or flutamide $(20 \mu \mathrm{M})$ (d). (1APPA: standard; PE: phosphoethanolamine; PC: phosphocholine; Pi: inorganic phosphate; GPE: glycerophosphorylethanolamine; GPC: glycerophosphorylcholine; NTP: nucleoside triphosphates; NAD: nucleotide adenine dinucleotide; DPDE: diphosphodiester sugars).

and their regulation is difficult to interpret [19]. Cellular content of GPE and GPC has recently been shown to at least in part reflect [26] the activity of the enzyme GPCphosphodiesterase. Future work to determine the mechanism of decreased GPC and GPE could concentrate on evaluation of the expression of these enzymes in Epi-1-treated cells.

\section{Conclusions}

The protein-protein interaction inhibitor Epi-1 induces changes in phospholipid metabolism which could be exploited in monitoring response of prostate cancer to this drug using ${ }^{31} \mathrm{P}$-NMR spectroscopy. 


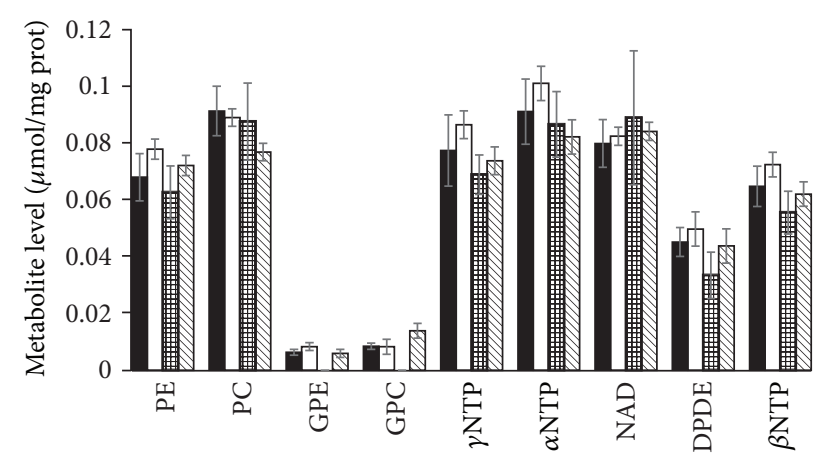

Figure 5: Mean $( \pm S D){ }^{31}$ P-NMR spectroscopy detectable metabolite content ( $\mu \mathrm{mol} / \mathrm{mg}$ protein) in control (untreated (black)), and pactitaxel $(5 \mathrm{nM})$ (white), Epi-1 $(40 \mu \mathrm{M})$ (squares), or flutamide $(20 \mu \mathrm{M})$ (diagonal) treated LNCaP cells.

\section{Conflicts of Interest}

The authors declare that there are no conflicts of interest regarding the publication of this article.

\section{Acknowledgments}

The authors gratefully acknowledge funding from Grampian NHS Endowment. The use of Professor Zanda's and Jaspar's NMR equipment and Russell Gray's assistance are also gratefully acknowledged.

\section{References}

[1] A. Jemal, F. Bray, M. M. Center, J. Ferlay, E. Ward, and D. Forman, "Global cancer statistics," CA: A Cancer Journal for Clinicians, vol. 61, no. 2, pp. 69-90, 2011.

[2] A. Heidenreich, P. J. Bastian, J. Bellmunt et al., "EAU guidelines on prostate cancer. Part II: treatment of advanced, relapsing, and castration-resistant prostate cancer," European Urology, vol. 65, no. 2, pp. 467-479, 2014.

[3] R. J. Andersen, N. R. Mawji, J. Wang et al., "Regression of Castrate-Recurrent Prostate Cancer by a Small-Molecule Inhibitor of the Amino-Terminus Domain of the Androgen Receptor," Cancer Cell, vol. 17, no. 6, pp. 535-546, 2010.

[4] V. Kruse, S. Van Belle, and V. Cocquyt, "Imaging requirements for personalized medicine: The oncologists point of view," Current Pharmaceutical Design, vol. 20, no. 14, pp. 2234-2249, 2014.

[5] S. Ammari, R. Thiam, C. Cuenod et al., "Radiological evaluation of response to treatment: application to metastatic renal cancers receiving anti-angiogenic treatment," Diagnostic and Interventional Imaging, vol. 95, no. 6, pp. 527-539, 2014.

[6] Y. Ma, W. Xu, R. Bai et al., "Volume-based predictive biomarkers of sequential FDG-PET/CT for sunitinib in cancer of unknown primary: identification of the best benefited patients," European Journal of Nuclear Medicine and Molecular Imaging, vol. 44, no. 2, pp. 199-205, 2016.

[7] S. C. Van Es, C. M. Venema, A. W. J. M. Glaudemans et al., "Translation of new molecular imaging approaches to the clinical setting: bridging the gap to implementation," Journal of Nuclear Medicine, vol. 57, pp. 96-104, 2016.
[8] I. N. Fleming, A. Andriu, and T. A. D. Smith, "Early changes in $[18 \mathrm{~F}] \mathrm{FDG}$ incorporation by breast cancer cells treated with trastuzumab in normoxic conditions: Role of the Akt-pathway, glucose transport and HIF-1 $\alpha$," Breast Cancer Research and Treatment, vol. 144, no. 2, pp. 241-248, 2014.

[9] A. Fodor, G. Berardi, C. Fiorino et al., "Toxicity and efficacy of salvage carbon 11-choline positron emission tomography/computed tomography-guided radiation therapy in patients with lymph node recurrence of prostate cancer," BJU International, 2016.

[10] F. Al-Saeedi, A. E. Welch, and T. A. D. Smith, "Choline incorporation into MCF7 tumour cells: Correlation with proliferation," European Journal of Nuclear Medicine and Molecular Imaging, vol. 32, no. 6, pp. 660-667, 2005.

[11] R. F. Kletzien and J. F. Perdue, "Sugar transport in chick embryo fibroblasts," The Journal of Biological Chemistry, pp. 249-3366, 1974.

[12] T. A. D. Smith and S. M. Phyu, "Metformin decouples phospholipid metabolism in breast cancer cells," PLoS ONE, vol. 11, no. 3, Article ID e0151179, 2016.

[13] T. Smith and S. Phyu, "Determination of Rate of [3H-methyl]choline Incorporation into Cellular Lipids and Non-lipid Metabolites," BIO-PROTOCOL, vol. 6, no. 22, 2016.

[14] A. L. Zhang, P. J. Russell, T. Knittel, and C. Milross, "Paclitaxel enhanced radiation sensitization for the suppression of human prostate cancer tumor growth via a p53 independent pathway," Prostate, vol. 67, no. 15, pp. 1630-1640, 2007.

[15] Y.-L. Chung, H. Troy, R. Kristeleit et al., "Noninvasive magnetic resonance spectroscopic pharmacodynamic markers of a novel histone deacetylase inhibitor, LAQ824, in human colon carcinoma cells and xenografts," Neoplasia, vol. 10, no. 4, pp. 303-313, 2008.

[16] S. M. Phyu, C.-C. Tseng, I. N. Fleming, and T. A. D. Smith, "Probing the PI3K/Akt/mTor pathway using 31P-NMR spectroscopy: Routes to glycogen synthase kinase 3," Scientific Reports, vol. 6, Article ID 36544, 2016.

[17] J. P. Wijnen, W. J. M. Van Der Kemp, M. P. Luttje, M. A. Korteweg, P. R. Luijten, and D. W. J. Klomp, "Quantitative 31P magnetic resonance spectroscopy of the human breast at 7 T," Magnetic Resonance in Medicine, vol. 68, no. 2, pp. 339-348, 2012.

[18] N. M. S. Al-Saffar, L. E. Jackson, F. I. Raynaud et al., "The phosphoinositide 3-kinase inhibitor PI-103 downregulates choline kinase $\alpha$ leading to phosphocholine and total choline decrease detected by magnetic resonance spectroscopy," Cancer Research, vol. 70, no. 13, pp. 5507-5517, 2010.

[19] M. Esmaeili, S. A. Moestue, B. C. Hamans et al., "In vivo $31 \mathrm{P}$ magnetic resonance spectroscopic imaging (MRSI) for metabolic profiling of human breast cancer xenografts," Journal of Magnetic Resonance Imaging, vol. 41, no. 3, pp. 601-609, 2015.

[20] B. F. Jordan, K. Black, I. F. Robey, M. Runquist, G. Powis, and R. J. Gillies, "Metabolite changes in HT-29 xenograft tumors following HIF- $1 \alpha$ inhibition with PX-478 as studied by MR spectroscopy in vivo and ex vivo," NMR in Biomedicine, vol. 18, no. 7, pp. 430-439, 2005.

[21] P. Popovics, D. E. Frigo, A. V. Schally, and F. G. Rick, “Targeting the 5/-AMP-activated protein kinase and related metabolic pathways for the treatment of prostate cancer," Expert Opinion on Therapeutic Targets, vol. 19, no. 5, pp. 617-632, 2015.

[22] J. B. Tennakoon, Y. Shi, J. J. Han et al., "Androgens regulate prostate cancer cell growth via an AMPK-PGC-1 $\alpha$-mediated metabolic switch," Oncogene, vol. 33, no. 45, pp. 5251-5261, 2014. 
[23] H. Li, J. Satriano, J. L. Thomas et al., "Interactions between HIF$1 \alpha$ and AMPK in the regulation of cellular hypoxia adaptation in chronic kidney disease," American Journal of Physiology - Renal Physiology, vol. 309, no. 5, pp. F414-F428, 2015.

[24] M. W. Lagemaat, M. C. Maas, E. K. Vos et al., "31P MR spectroscopic imaging of the human prostate at $7 \mathrm{~T}$ : T1 relaxation times, Nuclear Overhauser Effect, and spectral characterization," Magnetic Resonance in Medicine, vol. 73, no. 3, pp. 909-920, 2015.

[25] S. A. Moestue, G. F. Giskeodegard, T. F. Cao, I. S. Gribbestad, M. D. Cao, and T. F. Bathen, "Glycerophosphocholine (GPC) is a poorly understood biomarker in breast cancer," Proceedings of the National Academy of Sciences, pp. 109-E2506, 2012.

[26] J. P. Wijnen, L. Jiang, T. R. Greenwood et al., "Silencing of the glycerophosphocholine phosphodiesterase GDPD5 alters the phospholipid metabolite profile in a breast cancer model in vivo as monitored by 31P MRS," NMR in Biomedicine, vol. 27, no. 6, pp. 692-699, 2014. 


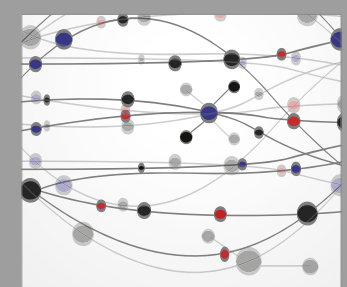

The Scientific World Journal
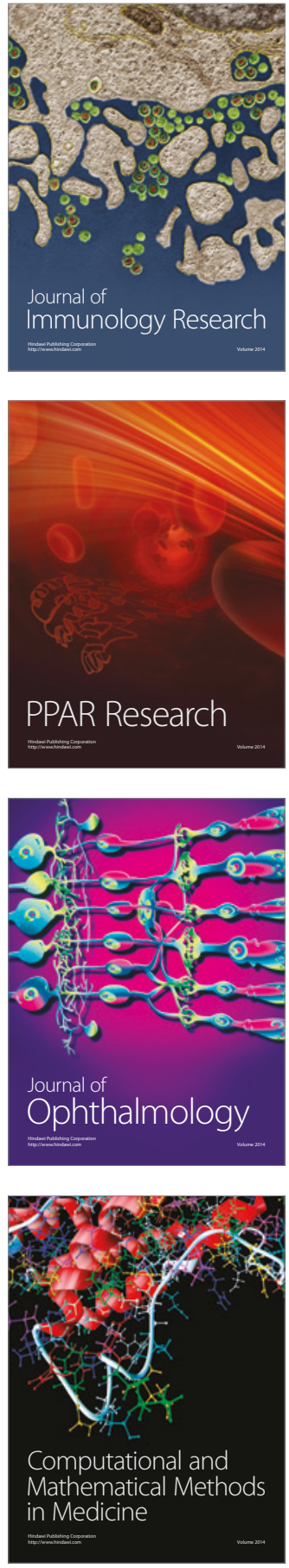

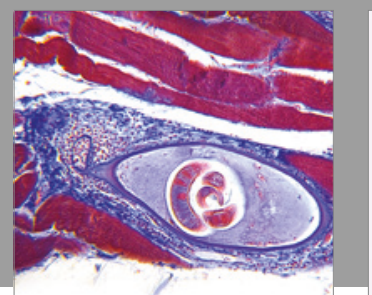

Gastroenterology Research and Practice
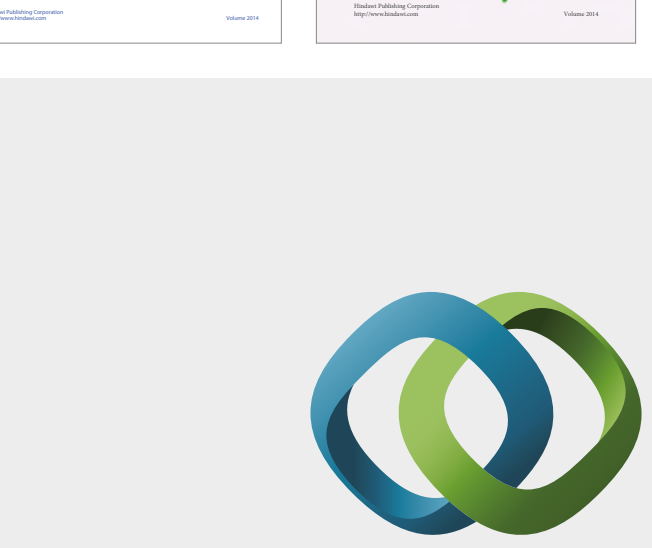

\section{Hindawi}

Submit your manuscripts at

https://www.hindawi.com
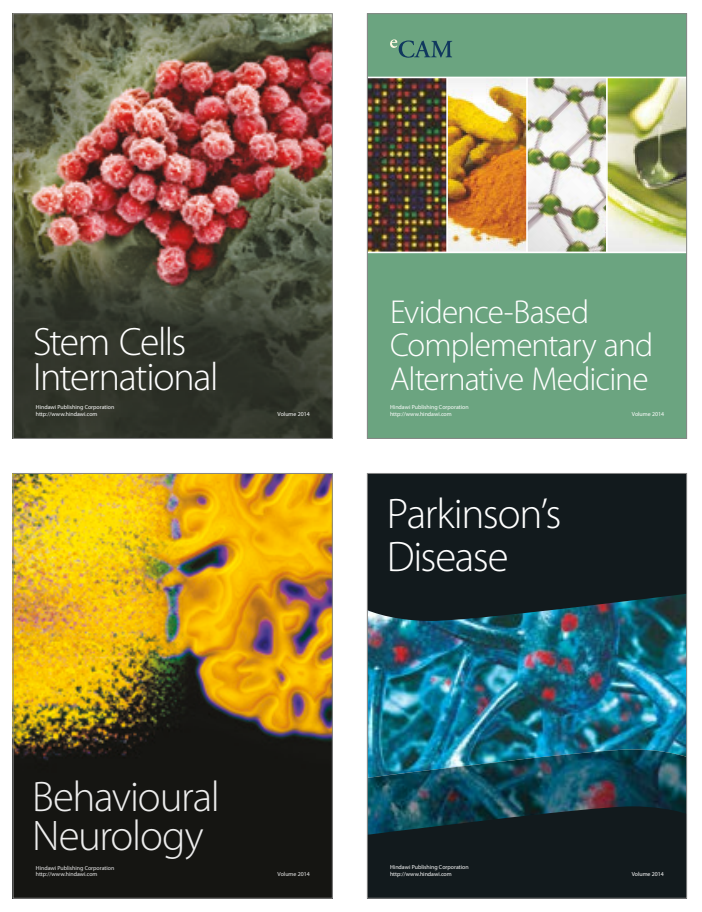
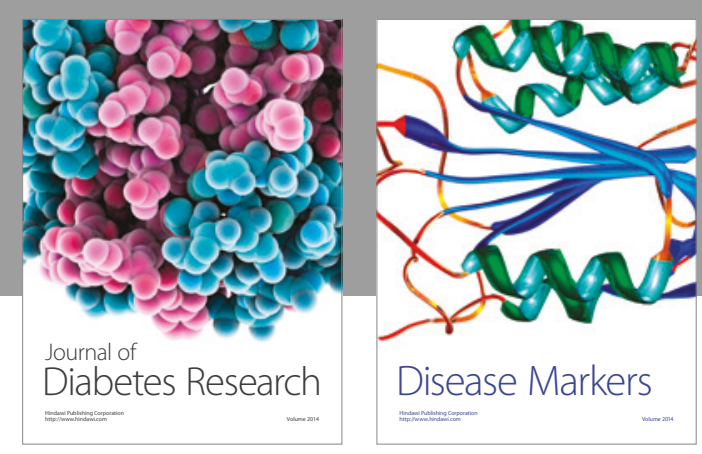

Disease Markers
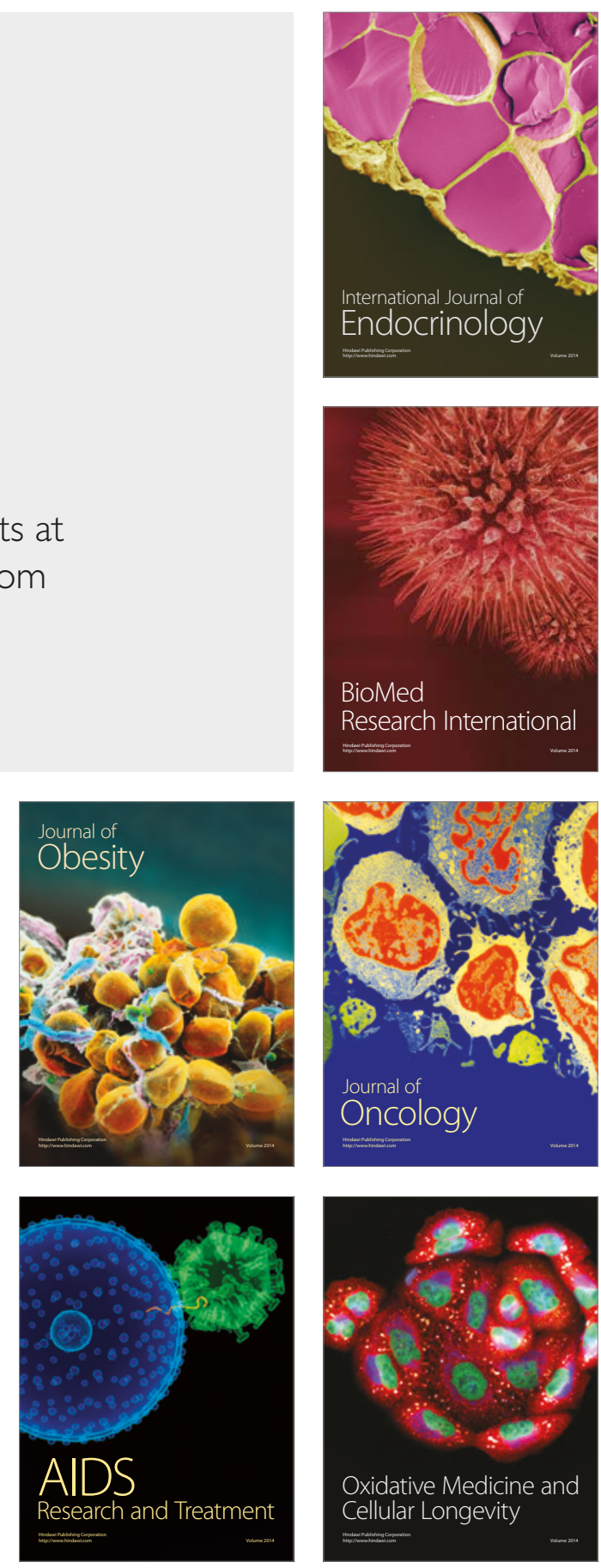